\title{
Measuring Self-Regulation of Distance Learners: A Comparative Study of Science and Arts Students
}

\author{
Farkhunda Rasheed Choudhary \\ Assistant Professor \\ Department of EPPS \& L, AIOU \\ farkhunda.rasheed@aiou.edu.pk \\ Dr. Azhar Mahmood \\ Associate Professor \\ Department of Education, IIU \\ Sidra Khushnood \\ M. Phil Scholar \\ Department of Science Education, AIOU
}

\begin{abstract}
In distance learning, students' self-regulation and autonomy has vital place. Learner's selfregulation is a major predictor of the academic success of distance learner. The high rate of selfregulation increases the quality of distance education. Therefore, it is important to explore that how much self-regulated the distance learners are in a distance education mode. This study aimed at exploring the self-regulation strategies of science and arts students studying in a distance learning university. The present study was descriptive in nature and survey was used for it. A sample of forty students was selected through purposive sampling. Learners' self-regulation was measured through research tool, having six constructs such as planning, monitoring, effort made by the distance learners to accomplish the course, self-efficacy, help-seeking situations, time and environment management situations. The data was collected through online questionnaire. It was found that distance learning science students were more self-regulated than arts students. Overall science students scored significantly higher grades than that of arts students. It is concluded that the science students are more self regulated due to self monitoring for their studies, more goal setting and more group interdependence. Goal setting and group interdependence can be considered as contributor for high GPA of distance learners. For science students, group interdependence is a good predictor of more GPA, however, for arts students, future orientation can be a predictor of good GPA. It is recommended that more interaction must be increased between instructor and arts students so that they can be more self-regulated about their studies.
\end{abstract}

Keywords: Self-regulation, Distance Learning, Science Students. 


\section{Introduction}

Distance learning is flexible, learner-centered and requires from learners to be selfregulated and to develop their learning skills independently (Dabbagh \& Kitsantas, 2009; Kuo \&Walker, 2010; Moore \& Kearsley, 2012). According to Zimmerman and Schunk (1989), selfregulation can be described as "the ability of learners to effectively engage in own learning process meta cognitive, motivationally and behaviorally" (Kocdar, Karadeniz, Bozkurt, \& Buyuk, 2018). Self-regulation is a complex term. Pintrich, (2000, p. 453) defined self-regulation as an active and constructive process in which the learners put an effort to observe, control and monitor their cognition. According to Pintrich, (2000) motivation plays important role for self-regulating the learners and ultimately change in behavior occurs when the learner has set their goals for learning. When learners control their cognition, motivation and behaviors while setting goals for their learning, they are guiding and controlling themselves by circumscribing their own learning environment. Self- regulated learning comprises goal-setting for learning, directed towards instructions, organizing ideas by employing effective tactics, using resources effectively, monitoring presentation, management of time, staying with positive beliefs about your competences (Duckworth, Akerman, MacGregor, Salter, \& Vorhaus, 2009).

Self-regulatory strategies are very important for distance learners as literature shows that self-regulation is highly demanded from a distance learner. A self-regulated learner can easily understand his/her needs and responsibilities. A self-regulated learner can set his/her goals and develops further plans to achieve these goals easily by avoiding unpleasant situations that impede his/her goals. Distance learning is therefore providing more flexible and personalized approach towards learning and learners are required to be more concerned and self-regulated in distance learning. Self-regulation is predictive of successful accomplishment of task (McClelland, et al., 2018). There are many researches that indicate that with greater score of self-regulation, students can score better academic achievement both in regular and distance learning modes (Cetin, 2015; Zimmerman \& Schunk, 2001). However, distance learners are more dependent upon their own self-regulation and motivation. Schunk, (2005) described that motivated control, such as selfregulation leads towards positive academic performance. Self-regulation therefore can be considered as an intrinsic motivational factor of the learner towards hi/her learning that contributes and affects his/her learning. This study aims to provide an insight into the self-regulatory strategies of distance learners. 


\subsection{Research Questions}

1. Is there any difference of self-regulation among the students of arts and science of the same distance university students?

2. What are the factors which contribute to the self-regulation of distance learners?

3. What are the factors which contribute to greater GPA of distance learners?

\subsection{Hypotheses}

$\mathrm{H}_{01}$. There is no significant difference regarding self-regulation between students of arts and science of the same distance university students.

$\mathrm{H}_{02}$. There is no significant difference regarding metacognitive strategies between students of arts and science of the same distance university students.

$\mathrm{H}_{03}$. There is no significant difference regarding motivational strategies between students of arts and science of the same distance university students.

$\mathrm{H}_{04}$. There is no significant difference regarding external factors effecting self regulation between students of arts and science of the same distance university students.

$\mathrm{H}_{05}$. There is no significant difference regarding group interactions between students of arts and science of the same distance university students.

$\mathrm{H}_{06}$. There is no significant difference regarding GPA of science and arts students of the same distance university students.

\subsection{Significance of Study}

In the distance learning mode, it is expected from the learner to be motivated and fully devoted for the learning (Lynch \& Dembo, 2004) as the learning is going on at the learners own pace. In distance learning mode, it is also expected from distance learners to emphasize on selfdirected learning that produces a sense of responsibility for the self-motivated learning. Everybody is not able to bear cognitive load, but the self-regulated learners can manage it in a better way (Seufert, 2018). Self-regulation strategies help the learners to attain higher academic goals (Matric, 2018). There are many other factors in distance learning such as learning habits, readiness, intelligence, thinking skills and motivation but the available literature suggested that selfregulation contributes much towards higher academic achievements of the learners (Ramli, 
Alavi, Mehrinezhad, \& Ahmadi, 2018) because the academic stress of distance learning can be mediated by self-regulatory strategies. As, distance learning is very much promoted now a days in Pakistan and the "Pakistan vision 2025" also emphasizes that "e-education, mobile-education and online distance learning as the paradigm of literacy shifts from pen to computers and tablets"(p.34), therefore, this study will be very much useful for the distance learning institutions to consider those factors which contribute to the self-regulation of the distance learner.

\subsection{Delimitations}

Focusing the time and resources, the proposed study was delimited in the following areas which can be explained as:

- The study was delimited to students of one distance learning university i.e. AIOU.

- The study was delimited in the main campus of Islamabad city only.

\section{Literature Review}

The self-regulation implies how well a learner manages his/her personal learning that is characterized by planning for study, monitor his/her learning process, regulate his/her own studies by overcoming barriers towards his/her learning. Zhao, (2016) quoted Pintrich, (2000) that selfregulation is an active and constructive process in which learners set goals of his/her own learning based on previous learning. Pintrich, (2000) studied the factors affecting learning of distance learner and found that self-regulation is one of the factors contributing for the success of distance and online learning environment that was based on a theoretical model. Pintrich, (2000) showed that student's self-regulation is affected by the learning environment. Moreover, Pintrich, (2000) revealed that self-regulation is a predictor of student's academic achievement which is further influenced by the learning environment or learning mode.

Zimmerman, (2008, p. 167) found that self-regulated learning is particularly important when personally directed mode of learning is applied. According to Zhao, (2016) the learners who are highly self-regulated can competently control, manage and regulate their own learning comprising their practices of goal setting, organizing and accomplishment of their learning goals and also they exhibit positive motivation and self-commitment and efficacy of fulfilling their learning tasks on their own. According to Zhao, (2016) there are three main self-regulated strategies that positively influence the academic output; firstly it was self-efficacy and goal 
orientation in the terms of motivation, secondly it was environment and situation management, thirdly it was help seeking behavior whereas Sharma, Dick, Chin, \& Land, (2007) found that environment and help asking comprises the learning environment and good learning environment bears the power to assist time and environment regulation.

According to Nikolaki, Koutsouba, Koutsouba, \& Venetsanou, (2017) learning autonomy of the student and active involvement is one of the characteristics of the distance learing. The authors were of the opinion that these two factors led towards self-regulation. The authors explored the relationship of the factors involving self-regulation in the context of distance learning and found that self-regulated learning as crucial for distance learning. Nikolaki et al., (2017) revealed that for optimal learning, it is very important to produce productive environment that can be created only through self-regulated learning. According to Zimmerman, (2000) this kind of learning demands self-regulated learning strategies in which the learner consciously controls the learning and regulate thoughts, emotoins and behavior so that a specific learing environment can be achieved . According to Daniela, (2015) motivational control and the process of self-regulation lead to positive conditioned results in the form of academic performance.

According to Kocdar, Karadeniz, Bozkurt, \& Buyuk, (2018) distance learning provides the learner with personalized learning experiences and it is flexible as in distance learning the learner can learn on his/her own place and time and he is responsible for controlling, monitoring and managing his/her own learning (Moore \& Kearsley, 2012). Distance learning being learner centered and having flexibility needs the learners to be more self-regulated (Kuo , Walker, Schroder, \& Belland, 2014, p. 8). According to Muller \& Seufert, (2018) learning that undergoes self-regulation activation processes often resulted in enhanced learning performance. Furthermore, self-regulation leads towards higher degree of self-efficacy. Amoozegar, Daud, Mahmud, \& Jalil, (2017) also quoted Muller and Seufert, (2018) that successful distance learning is possible only when there is institutional support is provided to the learners that also improves the quality of distance teaching/learning. Self-regulation plays a fundamental role in formal as well as distance learning for the accomplishment of all sorts of adaptive tasks in almost all stages of life (McClelland, et al., 2018). According to Chmiliar, (2011) during the last decade, there have been increasingly available sources of education through disatnce learning but it is very essential for the distance learners to self-regulate their learning as it has been appeared as a significant factor for successful learning. Chmiliar, (2011) agreed that self-regulation is a self directed learning 
process that enables the learner to transmitlearners' internal cognitive capabilities into learning skills and all this demands the application of some strategies. Chmiliar, (2011) studied the factors related to self-regulation that were time management, learning attitude, test performance and note taking behavior of the post secondary students that were enrolled in distance educational courses. It was found that students of distance learning educational setup, experience difficulties in the area of self-regulation regarding time management, self study time and accomplishment of learning tasks within given time frame.

According to Kirmizi, (2013) self-regulation enables the learners to take initiative with or without guidance of others in identifying needs, time management and discovering new learning resources. Kirmizi, (2013) found that distance learning students must increase their self-regulated learning habits. Kirmizi, (2013) quoted Schrum and Hong (2002) who explained that clear goal setting contributes in the academic performance of the distance learners. Kirmizi, (2013) also quoted Lynch and Dembo (2004) who argued that since distance education learners are not studying in fully controlled and structured classroom, therefore they must be able enough to create their own learning environment whether at home or anywhere else. Virtanen \& Nevgi, (2010) discussed the disciplinary differences on self-regulation of learners and found that learners of disparate disciplines of sciences demonstrated higher values of self-regulation than learners from arts disciplines. VanderStoep, Pintrich, \& Fagerlin, (1996) also explored the disciplinary differences on self-regulation among students of distinct disciplines including sciences and humanities. The overall results were in favor of the students having science disciplines.

Balapumi, Konsky, Aitken, \& McMeekin, (2016) described that university students are likely to self-monitor their own learning when these students continuously monitor their learning, however it is not easily possible for all learners to maintain self-regulation regarding their studies. Some learners need guidance and help to develop and maintain self-regulatatory strategies while learning. Balapumi at al., (2016) found that goal settings, self-efficacy, and metacognition has indirect impact on self-regulatory habits of learner and self-efficacy has significant effect on the self-regulation regarding learning of the distance university students. Students of distance education contemplated that self-studying behaviors, assignments, reports and reflection activities were very helpful for developing the learners into self-regulated learners (Ambreen, Haqdad, \& Saleem, 2016). 


\section{Methodology}

\subsection{Research Design}

The quantitative research design was used whereas survey method was employed to execute the research. The students of post-graduate courses served as the population for the study. The purposive sampling technique was used for this study. The students were asked to participate voluntarily in this research. The students who werewilling participate in the study were considered as the sample of the study. An online questionnaire was distributed to the willing participants of the study.

\subsection{Population}

The students enrolled in the post-graduate courses of all semesters from the sciences and arts group studying in Allama Iqbal Open University of Islamabad were the population for the proposed study.

\subsection{Sample and Sampling}

For this study, purposive sampling was used as the students of arts and science programmes were approached to participate in the study. The students who were willing to respondwere requested to fill the online form. There were 40 students whoserved as the sample of the study.

\subsection{Instrumentation}

The questionnaire was generated on Google forms and was distributed online to the participants of the study. The instrument developed by Al-Harthi, (2010) was adapted and it was validated from experts. The tool consisted of four sections. The first section of the tool composed of demographic information of the participants. The section two of the tool was composed of the factors affecting self-regulation of the learners in which four factors were observed that were authority, uncertainity avoidence, group interdependence, and future orientation. The third section of the instrument was composed of the self-regulation strategies in which two types were studied that were metacognitive and motivation. The metacognitive strategies were furthur grouped under four categories that were planning, self-monitoring, time and environment management, and helpseeking. The motivation strategies were grouped under two categories that were effort and selfefficacy. The fourth section of the instrument was composed of the distance education 
variables. The questionnaire was developed on 5-point likert scale starting from strongly disagree as 1 , disagree as 2 , neutral as 3 , agree as 4 and strongly agree as 5 . None of the items was negatively stated. The link of the questionnaire had been generated and was sent to the participants online. The content and face validity was ensured.

\section{Data Analysis}

Following is the data analysis of the study.

Table 1. Demographics

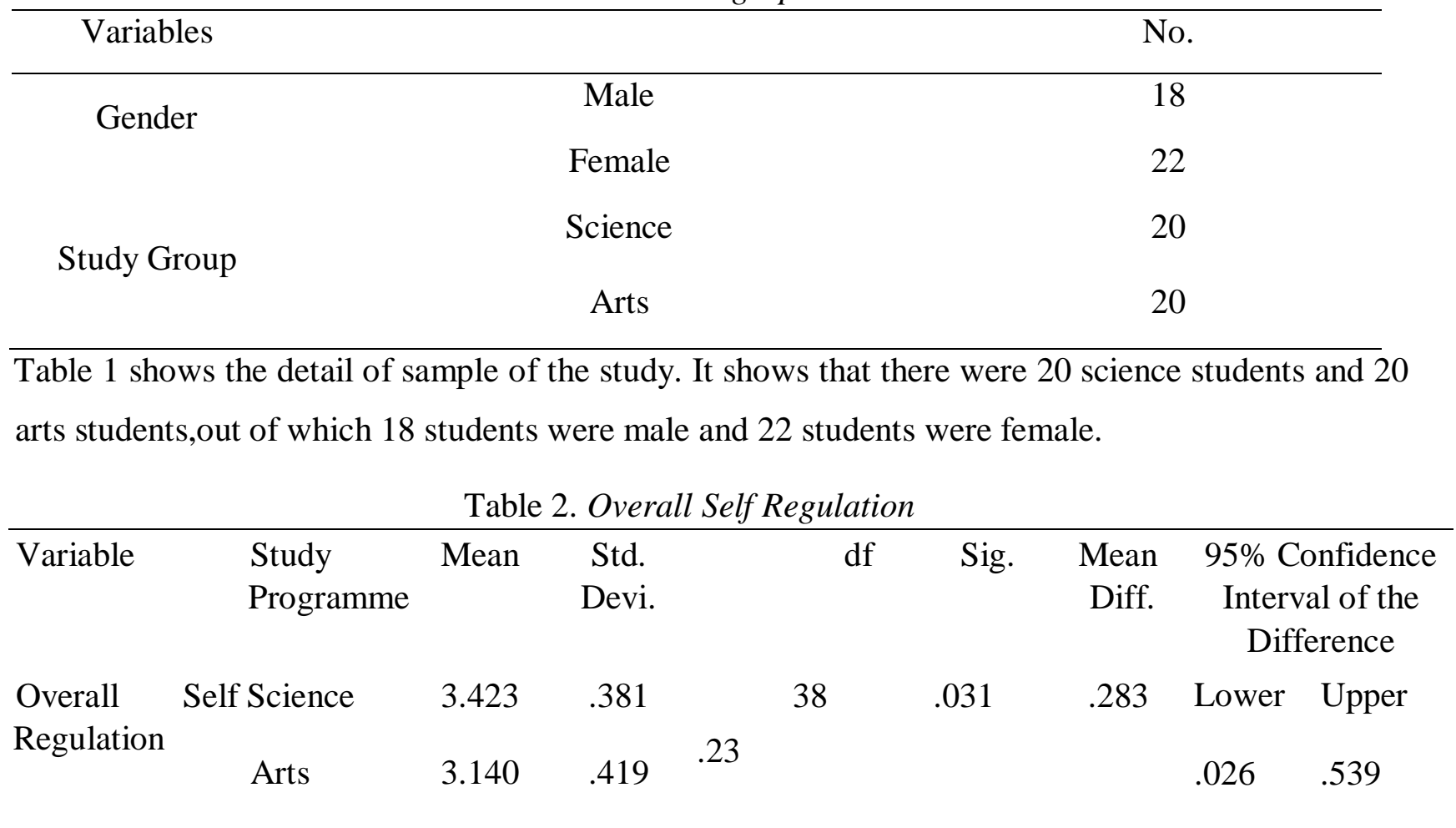

Table 2 shows the overall self regulation of science and arts students. It shows that there is significant difference of slef regulation of science and arts students. The science students were found more self regulated than arts students in distance learning mode. Therefore, first hypothesis has been rejected as there is significant difference regarding self regulation of sceince and arts students.

Table 3. Metacognitive Strategies

\begin{tabular}{lllllll}
\hline Variable & $\begin{array}{l}\text { Study } \\
\text { Programme }\end{array}$ & Mean & $\begin{array}{l}\text { Std. } \\
\text { Dev. }\end{array}$ & df & Sig. & $\begin{array}{l}\text { Mean } \\
\text { Diff. }\end{array}$ \\
& & & & $\begin{array}{l}\text { dence Confi- } \\
\text { the Difference }\end{array}$
\end{tabular}




\begin{tabular}{|c|c|c|c|c|c|c|c|c|c|c|}
\hline & & & & & & & & & Lower & Upper \\
\hline \multirow[t]{4}{*}{$\overline{\text { Plan }}$} & & & & & & 38 & .000 & .816 & .385 & 1.248 \\
\hline & Science & 0 & 3.48 & .532 & .831 & & & & & \\
\hline & & & 2.66 & .791 & & & & & & \\
\hline & & 0 & & & & & & & & \\
\hline \multirow{5}{*}{$\begin{array}{l}\text { Self } \\
\text { Monitoring }\end{array}$} & Science & & & & & 38 & .035 & .480 & .034 & .925 \\
\hline & & & 3.56 & .428 & & & & & & \\
\hline & & 0 & & & .181 & & & & & \\
\hline & Arts & & & & & & & & & \\
\hline & & & 3.08 & .885 & & & & & & \\
\hline \multirow{7}{*}{ Time } & & 0 & & & & & & & & \\
\hline & Science & & & & & 38 & .734 & .062 & -.307 & .432 \\
\hline & & & 3.12 & .559 & & & & & & \\
\hline & & 0 & & & 342 & & & & & \\
\hline & Arts & & & & & & & & & \\
\hline & & & 3.06 & .596 & & & & & & \\
\hline & & 0 & & & & & & & & \\
\hline \multirow{6}{*}{ Help } & Science & & & & & 38 & .423 & .160 & -.239 & .559 \\
\hline & & & 3.02 & .471 & & & & & & \\
\hline & & 0 & & & 811 & & & & & \\
\hline & Arts & & & & & & & & & \\
\hline & & & 2.86 & .745 & & & & & & \\
\hline & & 0 & & & & & & & & \\
\hline Overall & Science & & 3.29 & .426 & & 38 & .013 & .379 & .083 & .675 \\
\hline \multirow[t]{2}{*}{$\begin{array}{l}\text { Metacognitive } \\
\text { strategies }\end{array}$} & & 0 & & & .59 & & & & & \\
\hline & Arts & 0 & 2.91 & .502 & & & & & & \\
\hline
\end{tabular}

Table 3 shows the mean difference of one of self regulation variables i.e metacognitive strategies. It shows that there is significant difference of metacognitive strategies of science and arts students. Where science students were found more planned and have more self monitoring for their studies. Therefore, second hypothesis has been rejected as there is significant difference regarding meta cognitive strategies of sceince and arts students.

Table 4. Strategies

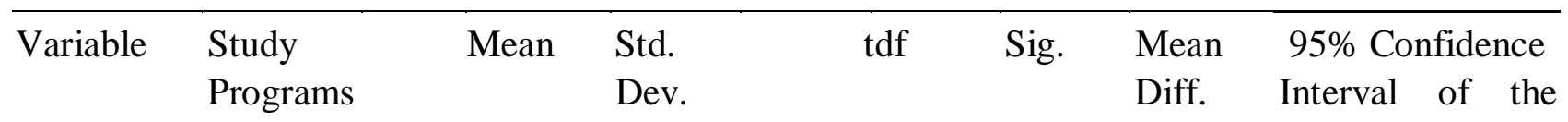




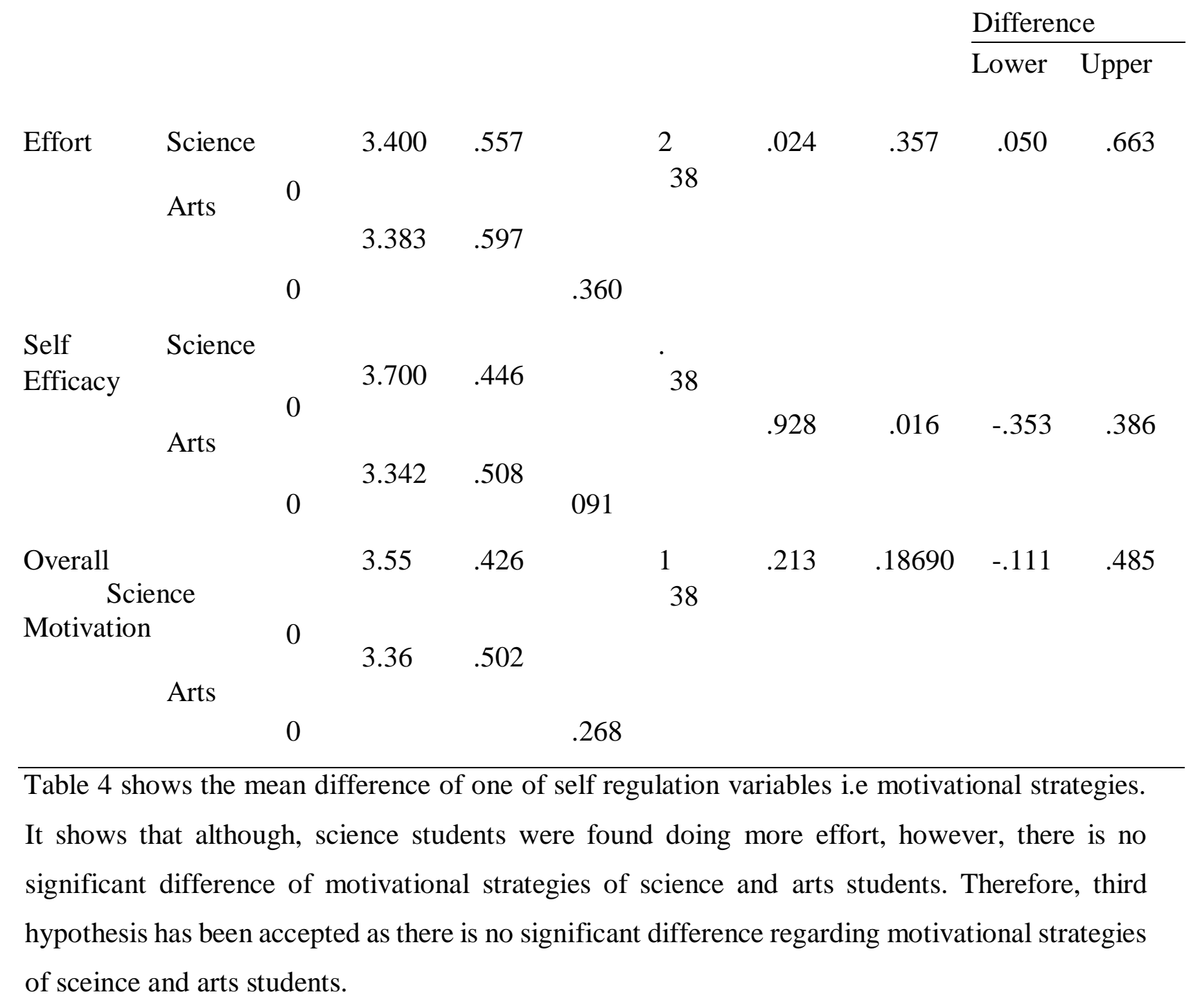

Table 5.External factors Effecting Self Regulation

\begin{tabular}{|c|c|c|c|c|c|}
\hline $\begin{array}{l}\text { Variables Study } \\
\text { Programme }\end{array}$ & NMean Std.Dev & $\mathrm{tDf}$ & Sig. & $\begin{array}{l}\text { Mean } \\
\text { Diff. }\end{array}$ & $\begin{array}{l}\text { 95\% Confidence } \\
\text { Interval of the } \\
\text { Difference }\end{array}$ \\
\hline
\end{tabular}


Lower Upper

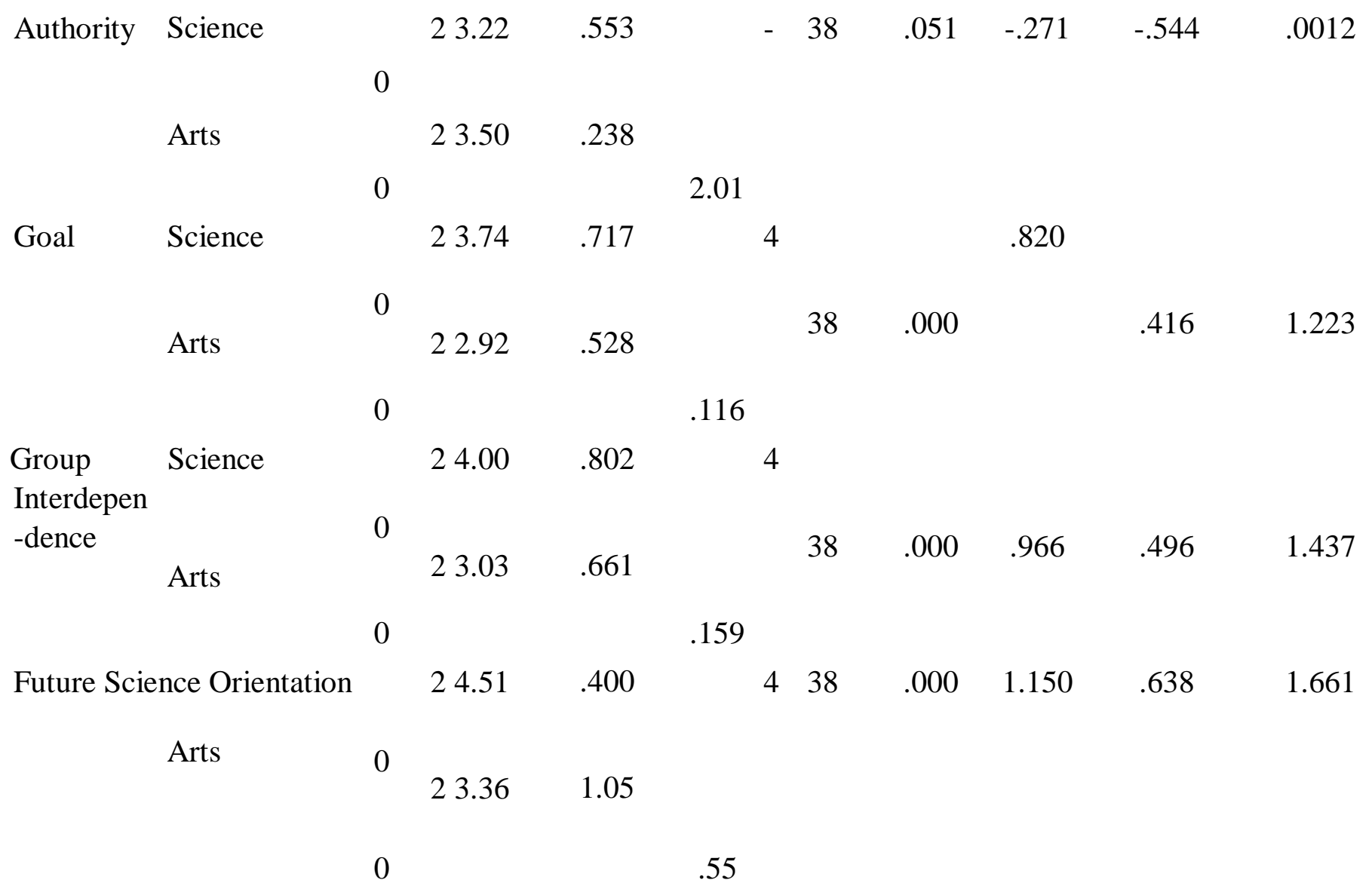

Table 5 shows that out of four external factors effecting self regulation of distance learners, significanct difference was found in three factors such as goal setting, group interdependence and furture orientation of science and arts distance learners.Science students were found more goal setters,group interdependence was found more among science students and future orientation of science students was more than students studying arts subjects in distance learning mode. Therefore, fourth hypothesis has been rejected as there is significant difference regarding three external factors effecting self regulation of sceince and arts students.

Table 6.Group Interactions

\begin{tabular}{lllllc}
\hline Variable & $\begin{array}{l}\text { Study } \\
\text { Program }\end{array}$ & Mean & $\begin{array}{l}\text { Std. } \\
\text { Deviation }\end{array}$ & df & $\begin{array}{c}\text { Sig. } \\
\text { Mean 95\% Confidence } \\
\text { Diff. Interval of the } \\
\text { Difference }\end{array}$
\end{tabular}




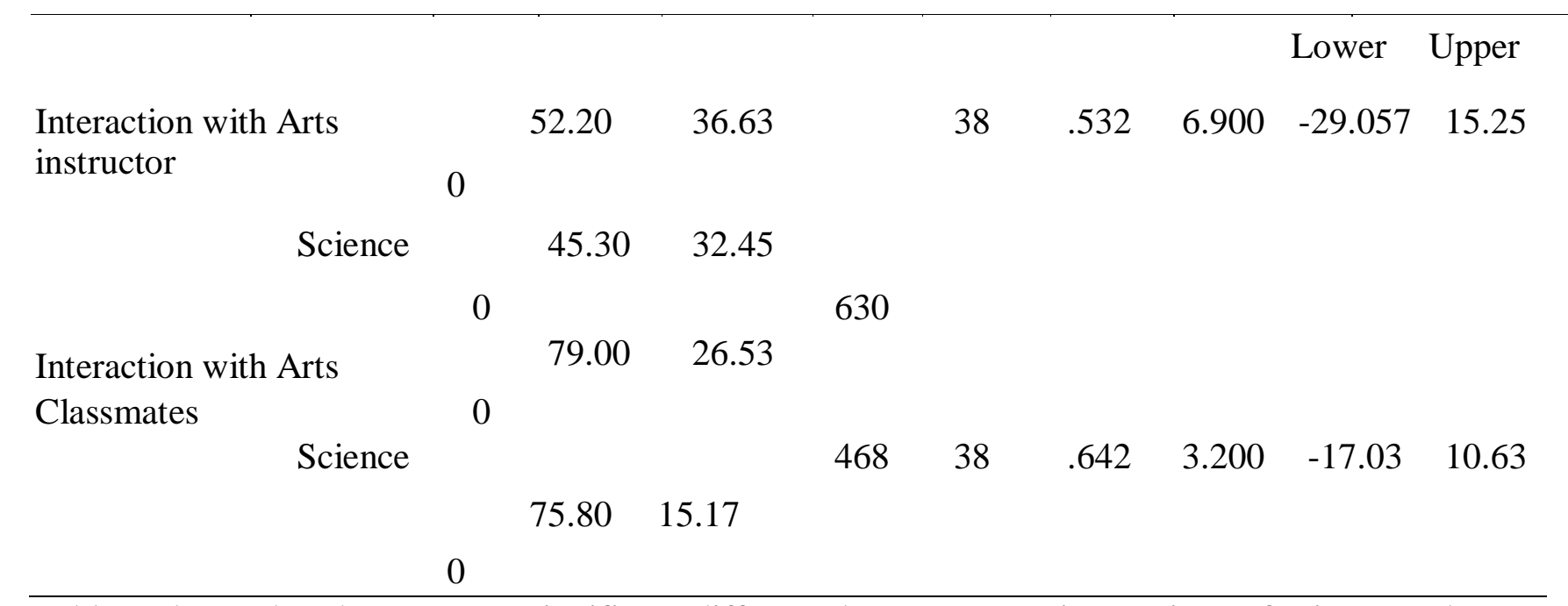

Table 6 shows that there was no significant differencebetweengroup interactions of science and arts students. Therefore, fifth hypothesis has been accepted as there is no significant difference regarding group interaction of sceince and arts students.

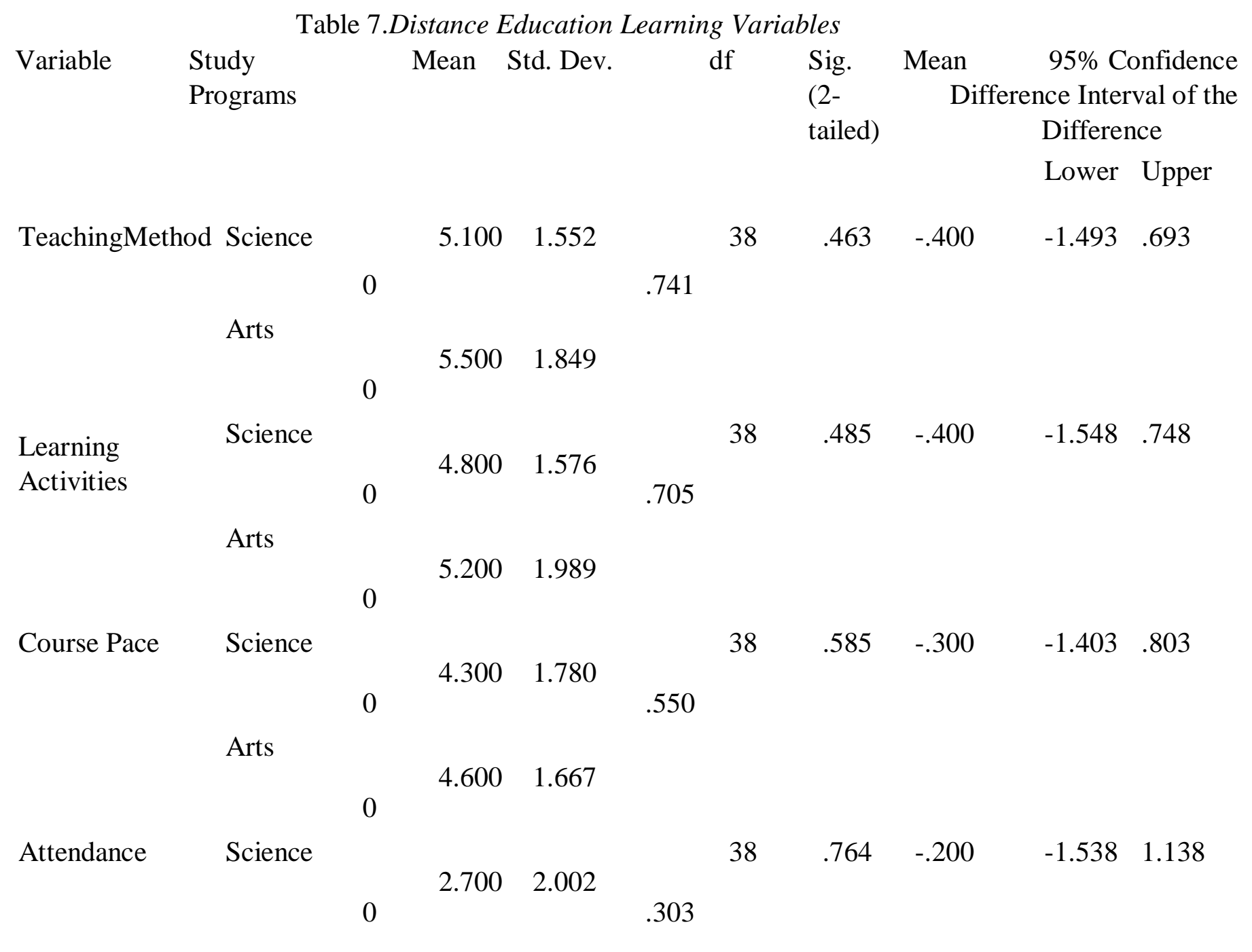




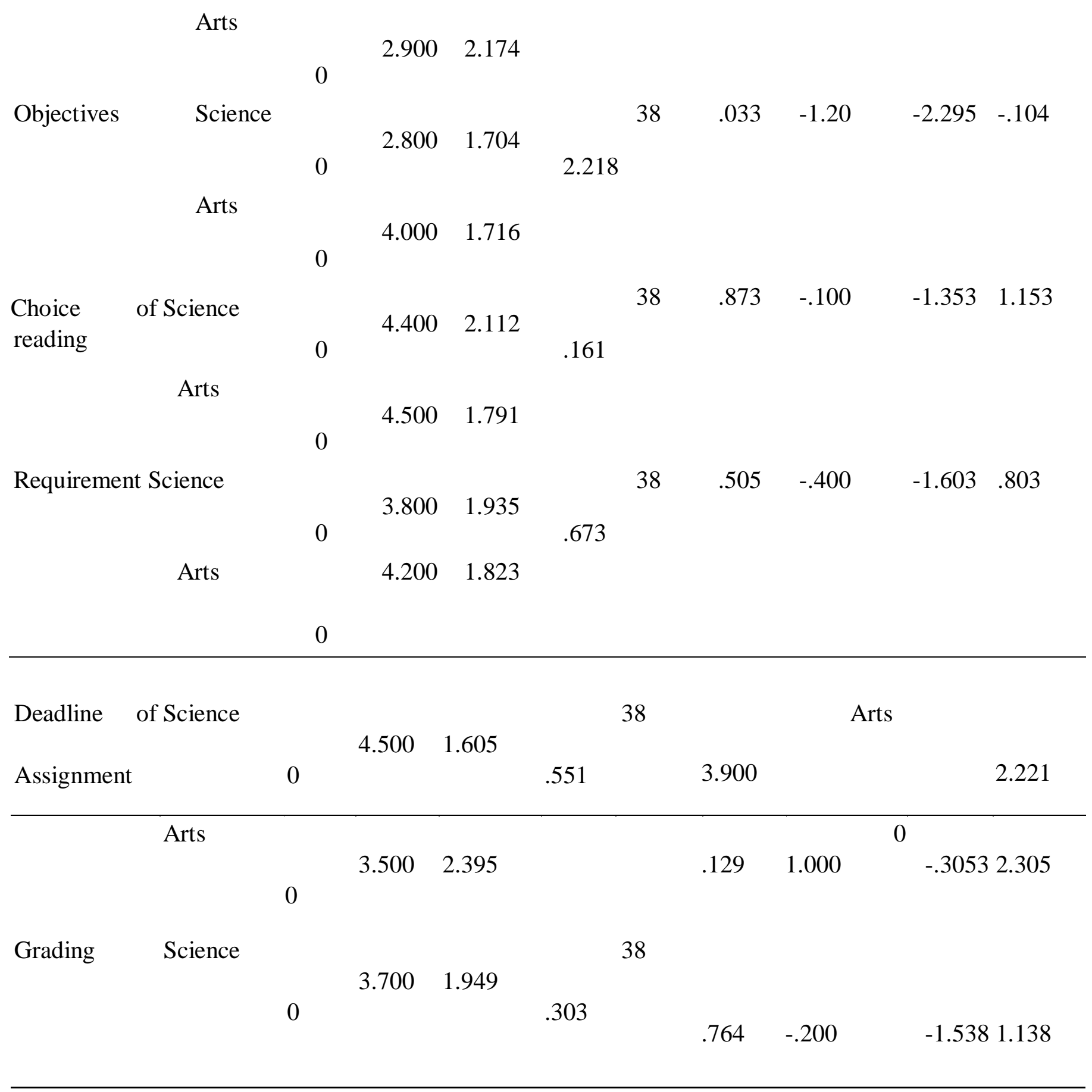

Table 7 shows mean difference of distance learning variables . Out of all variables, significant difference was found regarding objectives. Arts students were found satisfied that most of the objectives of distance education are being achieved.

Table 8. Comparison based on GPA of science and arts students

\begin{tabular}{llcccc}
\hline Variable & Study Programs & Mean & SE & t-value & p-value \\
\hline GPA & Arts & 2.29 & .393 & 2.44 & 0.01
\end{tabular}


Science

.146

Table 8 shows that there is significant difference of mean scores of GPA of science and arts distance learners. The science students were found to have more GPA than arts distance learners. Therefore, the sixth hypothesis has been rejected as there is significant difference regarding GPA of science and arts students of the same distance university students.

Table 9. Overall regression analysis showing factor of self-regulation leads to more GPA

\begin{tabular}{|c|c|c|c|c|c|c|c|}
\hline \multirow[b]{2}{*}{ Variable } & \multicolumn{2}{|c|}{$\begin{array}{l}\text { Un-standardized } \\
\text { Coefficients }\end{array}$} & \multicolumn{3}{|l|}{$\begin{array}{l}\text { Standardized } \\
\text { Coefficients }\end{array}$} & \multicolumn{2}{|c|}{$\begin{array}{l}\text { 95.0\% Confidence } \\
\text { Interval }\end{array}$} \\
\hline & & $\begin{array}{l}\text { Std. } \\
\text { Error }\end{array}$ & Beta & $\mathrm{t}$-value & p-vale & $\begin{array}{l}\text { Lower } \\
\text { Bound }\end{array}$ & $\begin{array}{l}\text { Upper } \\
\text { Bound }\end{array}$ \\
\hline \multirow[t]{2}{*}{ (Constant) } & - & & & -7.898 & .000 & -2.999 & -1.773 \\
\hline & 2.386 & 302 & & & & & \\
\hline \multirow[t]{2}{*}{ Authority } & & & .275 & 3.823 & .001 & .133 & .434 \\
\hline & 283 & 074 & & & & & \\
\hline \multirow[t]{2}{*}{ Goal } & & & .370 & 5.495 & .000 & .294 & .638 \\
\hline & 466 & 085 & & & & & \\
\hline \multirow[t]{2}{*}{ Group Interdependence } & & & .421 & 5.269 & .000 & .308 & .694 \\
\hline & 501 & 095 & & & & & \\
\hline \multirow[t]{2}{*}{ Future Orientation } & & & .226 & 3.173 & .003 & .151 & .688 \\
\hline & 419 & 132 & & & & & \\
\hline
\end{tabular}

Table 9 shows regression analysis. It shows that out of four external factors, goal setting and group interdependence were found to have more beta values predicting that these two factors might be considered for more GPA of distance learners.

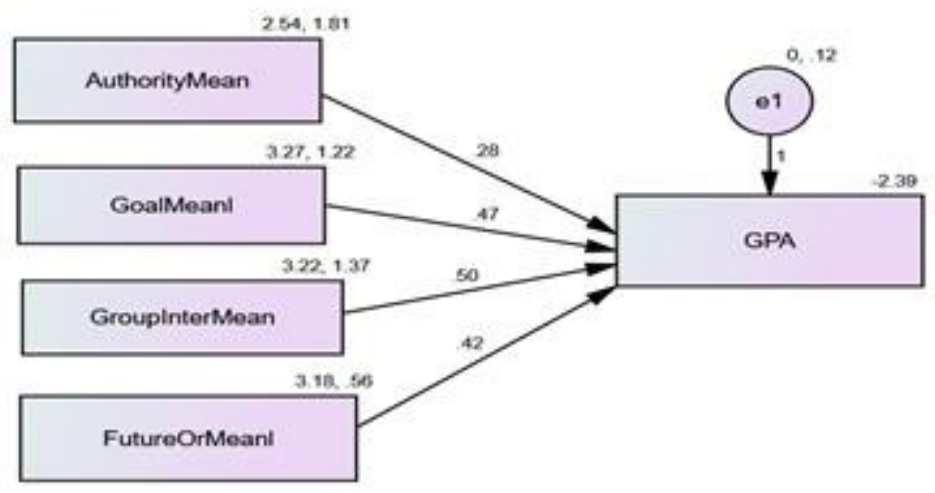




\section{Table 10.Regression analysis for GPA of Science students}

\begin{tabular}{|c|c|c|c|c|c|c|c|}
\hline & \multicolumn{2}{|c|}{$\begin{array}{l}\text { Un-standardized } \\
\text { Coefficients }\end{array}$} & \multicolumn{3}{|l|}{$\begin{array}{l}\text { Standardized } \\
\text { Coefficients }\end{array}$} & \multicolumn{2}{|c|}{$\begin{array}{c}95.0 \% \text { Confidence } \\
\text { Interval }\end{array}$} \\
\hline & $\underline{B}-$ & $\underline{\text { Std. Error }}$ & Beta & $\underline{\mathrm{t}}$ & p-value & $\begin{array}{l}\text { Lower } \\
\text { Bound }\end{array}$ & $\begin{array}{l}\text { Upper } \\
\text { Bound }\end{array}$ \\
\hline (Constant) & $2 . \overline{617}$ & .425 & & -6.152 & .000 & -3.524 & -1.710 \\
\hline Authority & .194 & .098 & .191 & 1.972 & .047 & -.016 & .403 \\
\hline Goal Setting & .590 & .113 & .488 & 5.218 & .000 & .349 & .831 \\
\hline $\begin{array}{l}\text { Group } \\
\text { Interdependence }\end{array}$ & .675 & .144 & .585 & 4.679 & .000 & .367 & .982 \\
\hline $\begin{array}{l}\text { Future } \\
\text { Orientation }\end{array}$ & .2332 & .226 & .112 & 1.029 & .0320 & -.249 & .715 \\
\hline $\mathrm{R}^{2}$ 0.97, Adjustec & 0.95 & F- & $2.5, p=0.000$ & & & & \\
\hline
\end{tabular}

Table 10 shows the regression analysis of GPA of science distance learners. It shows for science students, group interdependence has more beta value therefore it may be considered as predictor of more GPA.

Table 11. Regression analysis for GPA of Arts students

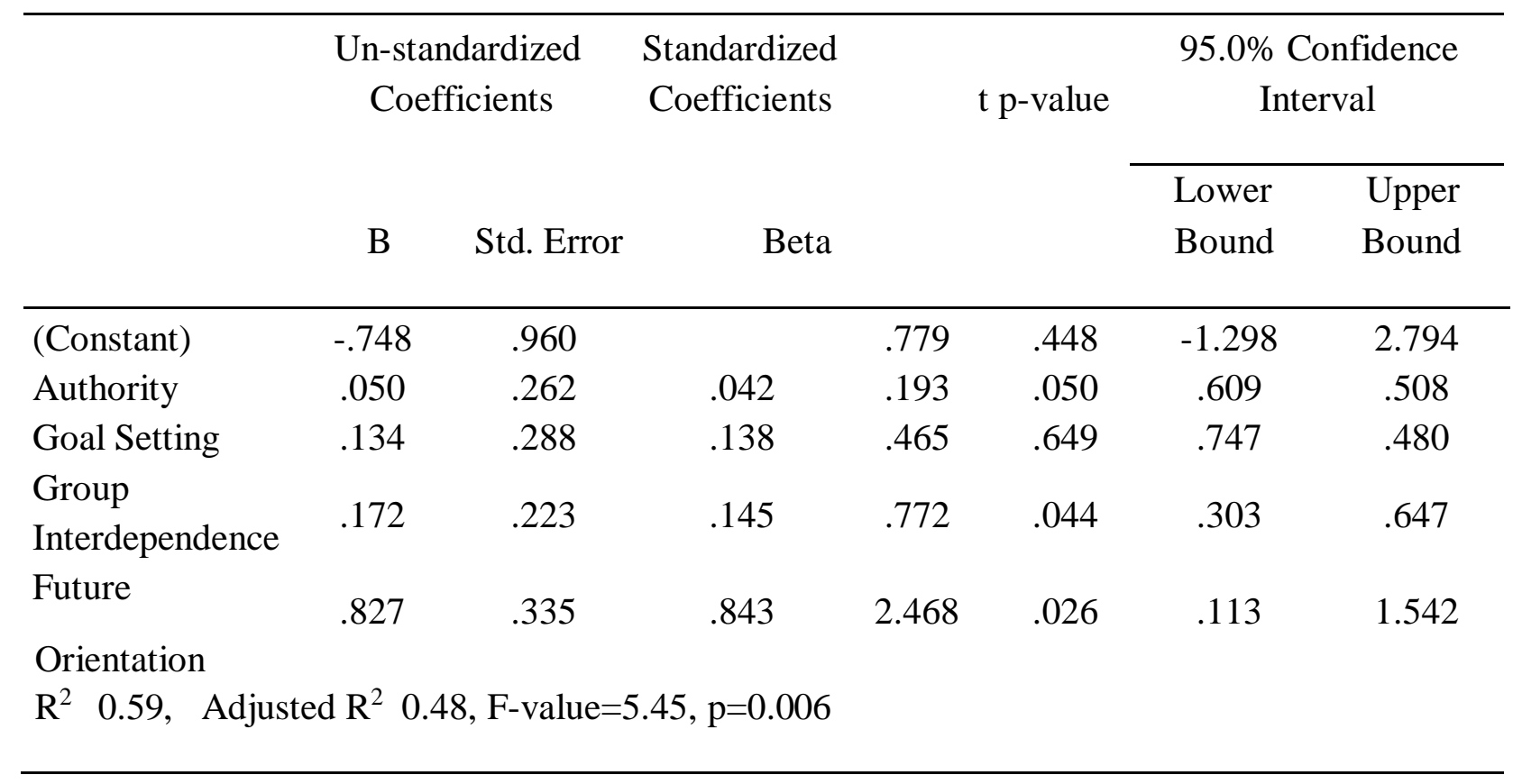

Table 11 shows the regression analysis of GPA of arts distance learners. It shows that for arts students, future orientation has more beta values therefore, it may be considered as predictor of more GPA. 


\section{Discussion}

This study was conducted to explore the self-regulation strategies of distance learners. The first research objective was to find the difference of self-regulation strategies of science and arts distance learners. Significant difference was found regarding self regulation of science and arts students. The science students were found more self regulated than arts students in distance learning mode. The findings of the study are in line with the Virtanen \& Nevgi, (2010).

The second objective of the study was to find the factors contributing the self regulation of the distance learners. The findings of the study showed that there was significant difference of metacognitive strategies of science and arts students. Where science students were found more planned and have more self monitoring for their studies. The findings of the study were in line to the VanderStoep, Pintrich, \& Fagerlin, (1996). It might be due to the fact that the distance learners science students have weekly classes that's why they were found more planned and have more self monitoring strategies than arts students. Similarly science students were found doing more effort, however, there is no significant difference of motivational strategies of science and arts students. the findings of the study are in line to the VanderStoep, Pintrich, \& Fagerlin, (1996).

As far as external factors are concerned, four external factors affecting students self regulation of distance learners were explored. Out of four factors, significanct difference was found in three factors such as goal seetting, group interdependence and furture orientation of science and arts distance learners. Science students were found more goal setters, group interdependence was found more among science students and future orientation of science students was more than students studying arts subjects in distance learning mode. The findings of the study are in line with the Virtanen \& Nevgi, (2010). The study also showed that there was significant difference of mean scores of GPA of science and arts distance learners. The science students were found to have more GPA than arts distance learners. It might be due to the routine quizzes and sessional workshops of distance learning science students. This finding of the study is in line with Virtanen \& Nevgi, (2010, p. 335).

In this study, regression analysis was also made to predict factors contributing to more GPA of distance learners. It was found that out of four external factors, goal setting and group interdependence were found to have more beta values predicting that these two factors might be considered for more GPA of distance learners. This finding is in line with the study of Vanderstoep, 
Pintrich, \& Fagerlin, (1996, p. 346). Furthermore, regression analysis was made to predict the variable contributing the good GPA for science and arts distance learners separately. It was found that for science students, group interdependence has more beta value therefore it may be considered as predictor of more GPA. Similarly, the regression analysis of GPA of arts distance learners showed that for arts students, future orientation has more beta values therefore, it may be considered as predictor of more GPA.

\section{Conclusion}

Form the findings and discussion of the study it is concluded that there is significant difference in the self regulation of science and arts students. The science students are more self regulated than arts students in distance learning mode. Similarly, science students are more planned and do more self monitoring for their studies. Similarly,science students were found more goal setters,group interdependence was found more among science students and future orientation of science students was more than students studying arts subjects in distance learning mode. Arts students studying in distance mode are more satisfied about the fulfillment of their programme objectives. The science students score more GPA than arts distance learners. Goal setting and group interdependence can be considered responsible for more GPA of distance learners. For science students, group interdependence is a good predictor of more GPA however, for arts students, future orientation can be a predictor of good GPA.

\subsection{Recommendations}

In the light of findings, following recommendations have been put forward.

1. Self-regulation of arts students might be increased by making them more organized. This can be done by arranging more scheduled learning activities.

2. Future orientation of science students can be increased by providing them more chances to explore future opportunities for studies and work.

3. Motivational strategies of science and arts students can be increased by more positive and timely feedback in distance learning mode. 
International Journal of Distance Education and E- Learning (IJDEEL) Volume V- Issue II (June, 2020)

4. Interaction of instructor with students and interaction among students must be increased for more clarity of distance learning mode.

\section{References}

Al-Harthi, A. S. (2010). Learner Self-Regulation in Distance Learning: A Creoss-Cultural Study . American Journal Of Distance Education, 1-4. doi:10.1080/08923647.2010.498232

Ambreen, M., Haqdad, A., \& Saleem, W. A. (2016). Fostering Self-Regulated Learning Through Distance Education: A Case Study of M.Phil Secondary Teacher Education Program of Allama Iqbal Open University. Turkish Online Journal of Distance Education, 17(03), 120135. Retrieved 2020, from http://tojde.anadolu.edu.tr/yonetim/icerik/makaleler/1178

Amoozegar, A., Daud, S. M., Mahmud, R., \& Jalil, H. A. (2017). Exploring Learner to Institutional Factors and Learner Characteristics as a Success Factor in Distance Learning. International Journal of Innovation and Research in Educational Sciences, 4(6), 647-656. Retrieved April 11, 2019

Balapumi, R., Konsky, B. R., Aitken, A., \& McMeekin, D. A. (2016). Factors influencing university students' self-regulation of learning: an exploratory study. ACSW '16 Proceedings of the Australasian Computer Science Week Multiconference. Canberra, Australia. doi:10.1145/2843043.2843067

Cetin, B. (2015). Academic Motivation And Self-Regulated Learning In Predicting Academic. Journal of International Education Research - Second Quarter , 11(2), 95-106. Retrieved April 8, 2018

Chmiliar, L. (2011). Self Regulation Skills and the Post Secondary Distance Learner. In P. -S. Sciences (Ed.), International Conference on Education and Educational Psychology (ICEEPSY 2011).29, pp. 318 - 321. Canada: Elsevier Ltd. doi:10.1016/j.sbspro.2011.11.245

Dabbagh, N., \& Kitsantas, A. (2009). Exploring How Experienced Online Instructors Report Using Integrative Technologies to Support Self-Regulated Learning. International Journal of Technology in Teaching and Learning, 5(2), 154-168. Retrieved April 7, 2018, from https://www.researchgate.net/publication/228400610_Exploring_How_Experienced_Onli ne_Instructors_Report_Using_Integrative_Technologies_to_Support_SelfRegulated_Lear ning

Daniela, P. (2015). The Relationship Between Self-Regulation, Motivation And Performance At Secondary School Students. (O. C. 2014, Ed.) Social and Behavioral Sciences, 191, 2549 - 2553 . doi:10.1016/j.sbspro.2015.04.410

Duckworth, K., Akerman, R., MacGregor, A., Salter, E., \& Vorhaus, J. (2009). Self-regulated learning: A literature review. Retrieved April 8, 2019, from http://www.projectlearnet.org/tutorials/sr_ef_routines.html

Kirmizi, O. (2013). Investigating Self-Regulated Learning Habits of Distance Education Students. Journal of History Culture and Art Research, 2(2), 161-174. doi:10.7596/taksad.v2i2.246 
Kocdar, S., Karadeniz, A., Bozkurt, A., \& Buyuk, K. (2018). International Review of Research in Open and Distributed Learning, 19(1). Retrieved April 8, 2019

Kuo, Y., Walker, A., Schroder, K., \& Belland, B. (2014). Interaction, Internet self-efficacy, and self-regulated learning as predictors of student satisfaction in online education courses. INTERNET AND HIGHER EDUCATION, 20, 25-50. doi:10.1016/j.iheduc.2013.10.001

Kuo, Y.-C., \& Walker, A. (2010). Interaction, Internet Self-Efficacy, and Self-Regulated Learning as Predictors of Student Satisfaction in Distance. All Graduate Theses and Dissertations. Retrieved April 7, 2019, from https://digitalcommons.usu.edu/etd/741

Lynch, R., \& Dembo, M. (2004). The Relationship between Self-Regulation and Online Learning in a Blended Learning Context . International Review of Research in Open and Distance Learning, 5(2). Retrieved November 15, 2019, from http://www.bwgriffin.com/gsu/courses/edur7130/content/correlation_ex1_regulation_lear ning.pdf

Matric, M. (2018). Self-Regulatory Systems: Self-Regulation and Learning. Journal of Process $\begin{array}{llll}\text { Management-New } \quad \text { Technologies, } & \text { International, }\end{array}$ doi:10.5937/jouproman619338

McClelland, M., Geldhof, J., Morrison, F., Gestsdottir, S., Cameron, C., Bowers, E., .. . Grammer, J. (2018). Self-Regulation. Handbook of Life Course Health Development. doi:10.1007/978-3-319-47143-3_12

Moore, M. G., \& Kearsley, G. (2012). Distance education : a systems view of online learning. Retrieved April 7, 2019

Muller, N. M., \& Seufert, T. (2018). Effects of self-regulation prompts in hypermedia learning on learning performance and self-efficacy. Learning and Instruction, 58, 1-11. Retrieved April 10, 2019, from http://doi.org/10.1016/j.learninstruc.2018.04.011

Nikolaki, E., Koutsouba, M., Koutsouba, M., \& Venetsanou, F. (2017). The Support and Promotion of Self-Regulated Learning in Distance Education. European Journal of Open, Distance and E-Learning. Retrieved April 9, 2019, from https://www.researchgate.net/publication/316627509_The_Support_and_Promotion_of_S elf_-_Regulated_Learning_in_Distance_Education

Pintrich, P. a. (2000). The Role Of Goal Orientation In Self-Regulated Learning. The handbook of self-regulation: Theory, research, and applications, 451-502. Retrieved April 8, 2019

Ramli, N. H., Alavi, M., Mehrinezhad, S. A., \& Ahmadi, A. (2018). Academic Stress and SelfRegulation among University Students in Malaysia: Mediator Role of Mindfulness. Behavioral Sciences , 8(12), 1-9. doi:10.3390/bs8010012

Schunk, D. (2005). Self-regulated learning: The educational legacy of Paul R. Pintrich. . Educational Psychologist, 40, 85-94. Retrieved April 8, 2019, from http://libres.uncg.edu/ir/uncg/f/D_Schunk_Self_2005.pdf

Seufert, T. (2018). The interplay between self-regulation in learning and cognitive load.

Educational Research Review, 24, 116-129.

doi:https://doi.org/10.1016/j.edurev.2018.03.004 
Sharma, S., Dick, G., Chin, W. W., \& Land, L. (2007). Self-Regulation and E-Learning. Retrieved April 9 , 2019 , from https://www.researchgate.net/publication/221409060_SelfRegulation_and_E-Learning

Vanderstoep, S. W., Pintrich, P. R., \& Fagerlin, A. (1996). Disciplinary Differences in SelfRegulated Learning in College Students. Contemporary Educational Psychology, 21(04), 345-362. Retrieved 2020, from http://citeseerx.ist.psu.edu/viewdoc/download

Virtanen, P., \& Nevgi, A. (2010). Disciplinary and Gender Differences Among Higher Education Students in Self-Regulated Learning Strategies. Educational Psychology: An International Journal of Experimental Educational Psychology, 30(03), 323347. doi:10.1080/01443411003606391

Zhao, H. (2016). Factors Influencing Self-Regulation in E-learning 2.0: Confirmatory Factor. Canadian Journal of Learning and Technology, 40(2). Retrieved April 9, 2019, from https://eric.ed.gov/?id=EJ1100654

Zimmerman, B. J. (2000). Attaining self-regulation: A social cognitive perspective. Handbook of regulations, 13-19. Retrieved April 9, 2019, from https://www.researchgate.net/publication/280751547_Attaining_selfregulation_A_social _cognitive_perspective

Zimmerman, B. J. (2008). Investigating self-regulation and motivation: Historical background, methodological developments, and future prospects. American Educational Research Journal, 45(1), 166-183. doi:10.3102/0002831207312909

Zimmerman, B., \& Schunk, D. (2001). Self-regulated learning and academic achievement: Theoretical perspectives (2nd ed.). Retrieved April 8, 2019 